\title{
Tissue selective effects of bazedoxifene on the musculoskeletal system in female mice
}

\author{
Christine A Cabelka ${ }^{1,2}$, Cory W Baumann ${ }^{1}$, Angus Lindsay ${ }^{1,3}$, Andrew Norton ${ }^{4}$, Nick C Blixt ${ }^{5}$, Gengyun Le ${ }^{1}$, \\ Gordon L Warren ${ }^{6}$, Kim C Mansky ${ }^{4}$, Susan A Novotny ${ }^{1,7}$ and Dawn A Lowe ${ }^{1}$
}

\author{
'Divisions of Rehabilitation Science and Physical Therapy, Department of Rehabilitation Medicine, Medical School, University of Minnesota, Minneapolis, \\ Minnesota, USA \\ 2Department of Physical Therapy, The College of St. Scholastica, Duluth, Minnesota, USA \\ 3Department of Biochemistry, Molecular Biology and Biophysics, University of Minnesota, Minneapolis, Minnesota, USA \\ ${ }^{4}$ Department of Developmental and Surgical Sciences, University of Minnesota, School of Dentistry, Minneapolis, Minnesota, USA \\ 5Department of Genetics, Cell Biology and Development, University of Minnesota, Minneapolis, Minnesota, USA \\ ${ }^{6}$ Department of Physical Therapy, Georgia State University, Atlanta, Georgia, USA \\ ${ }^{7}$ Gillette Children's Specialty Healthcare, Saint Paul, Minnesota, USA
}

Correspondence should be addressed to D A Lowe: lowex017@umn.edu

\begin{abstract}
The actions of selective estrogen receptor modulators are tissue dependent. The primary objective of the current study was to determine the tissue selective effects of bazedoxifene (BZA) on the musculoskeletal system of ovariectomized (OVX) female mice, focusing on the strengths of muscle-bone pairs in the lower hindlimb. Treatment with BZA after ovariectomy $(\mathrm{OVX}+\mathrm{BZA})$ did not prevent body or fat mass gains $(P<0.05)$. In vivo plantarflexor muscle isometric torque was not affected by treatment with BZA $(P=0.522)$. Soleus muscle peak isometric, concentric and eccentric tetanic force production were greater in $\mathrm{OVX}+\mathrm{BZA}$ mice compared to $\mathrm{OVX}+\mathrm{E}_{2}$ mice $(P \leq 0.048)$ with no effect on maximal isometric specific force $(P=0.228)$. Tibia from OVX+BZA mice had greater cortical crosssectional area and moment of inertia than OVX mice treated with placebo $(P<0.001)$, but there was no impact of BZA treatment on cortical bone mineral density, cortical thickness, tibial bone ultimate load or stiffness $(P \geq 0.086$ ). Overall, these results indicate that BZA may be an estrogen receptor agonist in skeletal muscle, as it has previously been shown in bone, providing minor benefits to the musculoskeletal system.
\end{abstract} Key Words

\section{Introduction}

As women age and progress through menopause, they experience a myriad of physiological and systemic changes including decreases in skeletal muscle function and bone health, increased incidence of hot flashes, and alterations in body composition, such as increased abdominal adiposity. There is evidence that menopausal hormone therapy is effective in mitigating these undesirable changes (Anderson et al. 2004, North American Menopause Society 2004, Greising et al. 2009, Ronkainen et al. 2009). However, since the Women's
Health Initiative raised concerns about the increased risk for thromboembolic events, stroke, and breast cancer for women using hormone therapy, the use of exogenous estrogens has declined substantially (Ettinger et al. 2012). This decline has prompted the development of a class of drugs known as selective estrogen receptor modulators (SERM). The ideal SERM will have an estrogenic effect on the target tissue(s), while at the same time have anti-estrogenic, or no effect, in non-targeted tissues. Bazedoxifene acetate (BZA) is a third-generation SERM. 
It was approved in the European Union for the prevention of postmenopausal osteoporosis in 2009, and then by the United States Food and Drug Administration in 2014 for use in combination with conjugated estrogens for treatment of moderate to severe hot flashes, as well as prevention of postmenopausal osteoporosis.

Results from the Selective Estrogen, Menopause, and Response to Therapy (SMART) trials indicate treatment with BZA and conjugated estrogen increases bone mineral density, improves sexual functioning in women with vulvar/vaginal atrophy, reduces the number and severity of hot flashes, prevents endometrial hyperplasia, and does not affect mammographic breast density (Pickar et al. 2009, Pinkerton et al. 2009, Harvey et al. 2013, Pinkerton et al. 2014).

While such clinical investigations have shown several positive effects of BZA, additional pre-clinical studies are necessary to further determine effects on targeted and nontargeted tissues, as well as the mechanisms through which BZA elicits these effects independent of a simultaneous estrogen treatment. In terms of efficacy on the skeleton, both rodent and primate models show treatment with BZA following ovariectomy (OVX) increases total bone mineral density (BMD), reduces OVX-induced bone turnover, and increases bone volume and trabecular thickness, particularly of the vertebrae (Kharode et al. 2008, Komm et al. 2011, Saito et al. 2015, Smith et al. 2015). Work by Borjesson et al. implicates estrogen receptor alpha (ER $\alpha)$, specifically the ER $\alpha$ - activation function-1, as a mechanism through which BZA elicits its effects in bone (Borjesson et al. 2013, Börjesson et al. 2016). While it appears BZA functions through ER $\alpha$ to mediate positive effects on BMD and turnover, there has been a minimal investigation into the effect of BZA on the mechanical properties of bone such as ultimate load and stiffness (Borjesson et al. 2013, Börjesson et al. 2016).

The effects of SERMs on skeletal muscle are largely unknown. This is important because skeletal muscle fibers, such as bone cells, contain estrogen receptors (Lemoine et al. 2003, Wiik et al. 2003, 2009). Some preclinical studies on mice have shown that OVX results in decreased skeletal muscle contractility, while treatment with estradiol $\left(\mathrm{E}_{2}\right)$ mitigates decreases (Moran et al. 2006, Greising et al. 2011a,b, Lai et al. 2016). Similarly, postmenopausal women who take estrogen-based hormone therapy have greater skeletal muscle strength than those who remain estrogen-deficient (Phillips et al. 1993, Greising et al. 2009, Ronkainen et al. 2009). Studies on female mice have also demonstrated that deletion of $E R \alpha$, specifically in skeletal muscle fibers, results in decreased skeletal muscle function (Ribas et al. 2016, Cabelka et al. 2019, Collins et al. 2018). While the SERM tamoxifen has been shown to be an estrogen receptor agonist in skeletal muscle as measured by positive effects on muscle strength (Warren et al. 2007), the extent to which BZA is an ER agonist in skeletal muscle is not known.

There is an inherent link between the function of the musculoskeletal system and physical activity. That is, as physical activity decreases so can skeletal muscle function and bone strength, whereas increasing physical activity can improve muscle function and bone strength. In mice, OVX causes significant decreases in levels of spontaneous physical activity and voluntary wheel running, while treatment with $\mathrm{E}_{2}$ can reverse or prevent the inactivity (Gorzek et al. 2007, Greising et al. 2011a, Bowen et al. 2012). Spontaneous physical activity has previously been defined as the home-cage activity or other activity that is different from motivated behaviors such as wheel running (Garland Jr et al. 2011). If BZA were to function such as $\mathrm{E}_{2}$ in terms of preventing OVX-induced declines in physical activity, that would be considered a beneficial effect. However, the extent to which BZA affects spontaneous physical activity in mice has been studied only minimally (Kim et al. 2014). Also, the extent to which BZA affects musculoskeletal function independent of any physical activity has not been thoroughly investigated. Thus, to more fully elucidate the tissue-specific properties of BZA, this study was designed to test the hypotheses that in ovariectomized mice BZA will (1) improve spontaneous physical activity over that of placebo, (2) be an ER agonist and have beneficial effects on skeletal muscle contractility, and (3) enhance bone structure and strength compared to treatment with placebo.

\section{Materials and methods}

\section{Animals and experimental design}

Thirty, 8-week-old, female C57BL/6 mice from Jackson Laboratories were obtained and group housed on a 14 $\mathrm{h}$ light:10 h darkness cycle, with free access to water and phytoestrogen free chow (Harland Teklad, 2919, Madison, WI, USA). After 3 week of acclimation and prior to any intervention, body composition was measured on conscious, 11-week-old animals (Echo MRI 3-in-1, Echo Medical System; Houston, TX, USA). Body mass was measured weekly, from the time of the first body composition measurement, for the duration of the study. 
Mice were randomly assigned to one of three treatment groups $(n=10$ each): OVX+placebo, OVX+BZA, and $\mathrm{OVX}+\mathrm{E}_{2}$. At 12-14 week of age mice underwent surgery. Two hours prior to ovariectomy surgery (Moran et al. 2006) mice received subcutaneous injections of 2 $\mathrm{mg} / \mathrm{kg}$ slow release buprenorphine (ZooPharm, Windsor, $\mathrm{CO}$, USA). Immediately following surgery, treatment pellets (placebo, BZA, or $\mathrm{E}_{2}$ ) were implanted at the base of the neck via a 10-gauge trochar (Innovative Research of America, Sarasota, FL, USA). One mouse each in the $\mathrm{OVX}+\mathrm{E}_{2}$ and $\mathrm{OVX}+\mathrm{BZA}$ groups were euthanized secondary to non-healing incisions after surgery.

The estrogen pellet consisted of $0.18 \mathrm{mg} 17 \beta-\mathrm{E}_{2}$, released over 60 days such that mice received approximately $3 \mu \mathrm{g} / \mathrm{day}$ (Innovative Research of America). This $\mathrm{E}_{2}$ dose was chosen to elicit physiological levels in mice (Nelson et al. 1981, Farr et al. 1995). The BZA pellet consisted of $1.44 \mathrm{mg} \mathrm{BZA}$, released over 60 days such that the mice received approximately $24 \mu \mathrm{g} /$ day. This dosage of BZA has been reported to be effective in protecting against bone loss (Andersson et al. 2016a,b), and was based on body surface calculations used to determine human doses (Reagan-Shaw et al. 2008, Silverman et al. 2008). BZA, a generous gift from Pfizer Inc., was sent to Innovative Research of America to make BZA time-release pellets (Wardell et al. 2013).

Spontaneous physical activity was quantified using 24-h cage activity monitoring at 7 week of treatment, body composition was remeasured at 8 week of treatment, and then in vivo and in vitro skeletal muscle function was analyzed, immediately followed by sacrifice. At sacrifice, uteri, as well as subcutaneous and visceral fat pads, were dissected and weighed. Blood was then collected by cardiac bleed, and was allowed to clot at room temperature followed by centrifugation for $10 \mathrm{~min}$ at $10,000 \boldsymbol{g}$ at room temperature. Serum, void of red cell hemolysis, was extracted, snap-frozen in liquid nitrogen, and then stored at $-80^{\circ} \mathrm{C}$ until analyzed for $\mathrm{E}_{2}$ or BZA. Lastly, tibial bones were removed, cleaned of all soft tissue, snap-frozen in tubes containing $1 \mathrm{~mL} \mathrm{PBS}$, and stored at $-80^{\circ} \mathrm{C}$ until bone density and structure measurements and mechanical testing were completed.

The University of Minnesota Institutional Animal Care and Use Committee approved all protocols and animal care procedures. Measurements of serum BZA and $\mathrm{E}_{2}$, physical activities, body mass and composition, in vivo and in vitro muscle physiology, and bone density and strength were conducted with investigators blinded to mouse treatment.

\section{Serum $E_{2}$ concentration}

Serum was pooled when necessary to reach $>300 \mu \mathrm{L}$ per sample to be analyzed, precipitated, eluted, and measured using liquid chromatography - tandem mass spectrometry (LC-MS/MS) as previously described (Le et al. 2018). Briefly, a micro LC column $(2.7 \mu \mathrm{m}, \mathrm{C} 1890 \AA$, Halo Fused core, $100 \times 0.3 \mathrm{~mm}$, Eksigen, SCIEX; Framingham, MA, USA) was used in series with an AB SCIEX QTRAP 5500 mass spectrometer (Thermo Fisher Scientific). The $\mathrm{E}_{2}$ reporter was identified by a $\mathrm{m} / \mathrm{z}$ of $271.2 \mathrm{Da}$ and quantified by the peak area of the chromatograph using MultiQuant ${ }^{\mathrm{TM}}$ (SCIEX). Mean serum concentrations of $\mathrm{E}_{2}$ were: $\mathrm{OVX}+$ placebo $=4.7$ $\mathrm{pg} / \mathrm{mL}$ ( $n=4$, pooled samples), $\mathrm{OVX}+\mathrm{E}_{2}=44.9 \pm 27.9 \mathrm{pg} / \mathrm{mL}$ ( $n=5$, unpooled samples with $\mathrm{SD}$ ) indicating successful ovariectomy and replacement of $\mathrm{E}_{2}$ in the physiological range for female mice, respectively.

\section{Serum BZA concentration}

Serum samples were thawed on ice and an equal volume of acetonitrile was added to each. Samples were vortexed, place on ice for $10 \mathrm{~min}$ followed by centrifugation at $4^{\circ} \mathrm{C}$ and $20,817 \boldsymbol{g}$ for $10 \mathrm{~min}$, and the supernatant was used for analysis. Samples were spiked with $5 \mathrm{ng} / \mathrm{mL}$ BZA standard prior to analysis.

HPLC measurement of BZA was performed using a Shimadzu I-series 2030C with auto-sampler, RF-20A fluorescence detector and online degasser with $10 \mu \mathrm{L}$ of each sample injected onto a Luna $5 \mu \mathrm{m}$ C-18 $100 \AA$, 250 $\times 4.6 \mathrm{~mm}$ column (Phenomenex, CA, USA). The mobile phase was generated by mixing (A) $10 \mathrm{mM} \mathrm{KH}_{2} \mathrm{PO}_{4}(\mathrm{pH} 3$ ) with (B) 10:90 water:acetonitrile (v:v) by pre-pump mixing to give $90 \% \mathrm{~A}$ and $10 \% \mathrm{~B}$ at $1 \mathrm{~mL} / \mathrm{min}$. BZA was eluted with a linear gradient from 10 to $90 \%$ B over 30 min and followed by $90 \%$ B for a further $10 \mathrm{~min}$. The column was returned to the starting condition by $90-10 \%$ B gradient over 2 min and holding at 10\% B for 3 min making a total run time of $45 \mathrm{~min}$. BZA was detected at its natural fluorescence of $300 \mathrm{~nm}$ excitation and $380 \mathrm{~nm}$ emission (Chandrasekaran et al. 2010). The concentration and identity of BZA was compared to a standard, bazedoxifene acetate (Pfizer Inc.). Concentration was quantified by peak area using Shimadzu Class VP software. Serum BZA concentrations were (mean \pm s.D.): $\mathrm{OVX}+$ placebo $=0.19$ $\pm 0.47 \mathrm{ng} / \mathrm{mL}(n=4), \mathrm{OVX}+\mathrm{BZA}=3.62 \pm 6.27 \mathrm{ng} / \mathrm{mL}(n$ $=10)$, and $\mathrm{OVX}+\mathrm{E}_{2}=-0.08 \pm 0.37 \mathrm{ng} / \mathrm{mL}(n=4)$. These BZA concentrations are consistent with previous reports (Chandrasekaran et al. 2010, Smitha et al. 2015). 


\section{4-h physical activity monitoring}

Using open-field activity chambers (Med Associates Inc., St. Albans, VT, USA) for a 24-h period, spontaneous physical activities of individual mice were measured as previously described (Landisch et al. 2008, Greising et al. 2011a). Briefly, each mouse underwent a familiarization period by being housed in a mock chamber for a full day prior to initiating the 24-h cage activity monitoring on the second day. Activity data were acquired using Activity Monitor version 5 software (Med Associates), and a box size of three. Disruption of photo beam arrays in the chamber due to mouse movements register an activity count and duration. To note, an 'activity count' represents any single photo beam break and because multiple photo beams may break with one jump or vertical movement, those counts do not represent the actual number of times a mouse jumps or rears. One mouse from each of the $\mathrm{OVX}+$ placebo and $\mathrm{OVX}+\mathrm{E}_{2}$ groups had data excluded in the analysis secondary to software malfunction.

\section{In vivo plantar flexor muscle function}

Each mouse was anesthetized via isoflurane inhalation (1.5\%) with an $\mathrm{O}_{2}$ flow rate of $125 \mathrm{~mL} / \mathrm{min}$ and in vivo contractility of the plantar flexor muscles (gastrocnemius, soleus, and plantaris) was assessed by stimulating the sciatic nerve. As previously described, the peroneal branch of the sciatic nerve was first severed to avoid recruitment of the dorsi flexor muscles (Baltgalvis et al. 2012). The ankle joint was positioned so that the foot was perpendicular to the tibia and the knee was stabilized with a clamp to inhibit lower limb movement. The footplate was attached to the shaft of a servomotor (300-LR; Aurora Scientific, Aurora, Ontario, Canada). Peak isometric torque was measured, followed by a series of concentric contractions at various angular velocities $\left(1200-100^{\circ} / \mathrm{s}\right)$ of plantarflexion over a $40^{\circ}$ excursion. Contraction of the plantar flexors was elicited via percutaneous stimulation of the sciatic nerve with platinum needle electrodes attached to a stimulator (E2-12 electrodes and S48 stimulator; Grass Telefactor, Warwick, RI, USA). While still anesthetized, mice received an intraperitoneal injection of sodium pentobarbital (100 $\mathrm{mg} / \mathrm{kg}$ body mass) followed by in vitro contractility testing of the soleus muscle.

\section{In vitro soleus muscle contractile function}

Soleus muscle isolation and preparation have previously been described (Moran et al. 2005). Briefly, the soleus muscle was placed in a $1.2 \mathrm{~mL}$ bath filled with oxygenated Krebs-Ringer buffer maintained at $25^{\circ} \mathrm{C}$. The proximal muscle tendon was attached by 6-0 suture to a dual-mode muscle lever system (300BLR; Aurora Scientific Inc.). Measures of peak isometric, concentric, and eccentric forces during tetanic stimulation were obtained as previously described (Greising et al. 2011b).

\section{Cortical bone structure of the tibia}

Cortical bone of tibia at the mid-diaphysis was assessed using a micro-CT system (XT H 225, Nikon Metrology Inc.). The scanner was set to a voltage of $120 \mathrm{kVp}$ and a current of $61 \mu \mathrm{A}$, and bones were scanned using an isotropic $7.4 \mu \mathrm{m}$ voxel size with a $708 \mathrm{~ms}$ integration time. A $0.5 \mathrm{~mm}$ region (approximately 68 slices) was scanned and the average relative bone density was determined at each slice using regression analyses derived from Image J (NIH) analysis based on standardized phantoms (Bruker micro-CT, Belgium). The average BMD across each of the 68 slices was calculated and reported for each tibia. CT Pro 3D (Nikon Metrology Inc.) was used to make 3D reconstruction volumes for each scan. VGStudio MAX 3.2 (Volume Graphics GmbH, Heidelberg, Germany) converted 3D reconstruction volumes to bitmap datasets for each scan. Morphometric analyses were completed with the SkyScan CT-Analyzer (Bruker micro-CT). At completion of scanning, bones were stored at $-80^{\circ} \mathrm{C}$ until mechanical testing.

\section{Bone mechanical testing}

Mechanical properties of the tibia at the mid-diaphysis were determined using three-point bending. A Mecmesin MultiTest 1-D test machine and a Mecmesin AFG-25 load cell (Mecmesin, West, Sussex, UK) was used as previously described (Novotny et al. 2011). Briefly, each tibia was thawed, length measured, and the mid-point was marked. Each bone was placed on its lateral side on two supports with $1 \mathrm{~cm}$ separation and a quasi-static load was applied to the mid-diaphysis at a displacement rate of $2 \mathrm{~mm} / \mathrm{min}$ until failure. Load-displacement curves were analyzed for each bone using a custom-written TestPoint program (TestPoint version 7; Measurement Computing Corp., Norton, MA, USA) as previously described (Novotny et al. 2011, Mader 2014). Mechanical properties analyzed were ultimate load and stiffness. 
Table 1 Twenty-four hour cage activities of ovariectomized mice treated with placebo, bazedoxifene, or $17 \beta$-estradiol for

7 weeks.

\begin{tabular}{lccc}
\hline & OVX+Placebo $(n=9)$ & & OVX+BZA $(n=9)$ \\
\cline { 1 - 1 } Ambulation distance $(\mathrm{m})$ & $1211(918)$ & $549(370)^{\mathrm{a}}$ \\
Ambulation time (min) & $148(37.4)$ & & $92.7(43.8)$ \\
Jump count & $1611(484)$ & & $1423(514)$ \\
Vertical count & $6206(3315)$ & $2200(1558)$ \\
Active time (min) & $284(43.3)$ & $221(43.4)$ \\
\hline
\end{tabular}

$\begin{array}{r}\hline \mathbf{O V X}+\mathbf{E}_{\mathbf{2}}(n=8) \\ \hline 1155(1129) \\ 148(70.3) \\ 2109(757) \\ 11,934(13,109) \\ 290(80.5) \\ \hline\end{array}$

\begin{tabular}{c}
\hline One-way ANOVA $\boldsymbol{P}$-value \\
\hline 0.020 \\
0.062 \\
0.065 \\
0.066 \\
0.042 \\
\hline
\end{tabular}

Data are means (S.D.).

aDifferent from OVX+Placebo.

\section{Statistical analyses}

To analyze the effects of treatment $(\mathrm{OVX}+$ placebo, $\mathrm{OVX}+\mathrm{BZA}, \mathrm{OVX}+\mathrm{E}_{2}$ ) and time (baseline/pre-surgery, $\mathrm{OVX}$, weeks 1-8) on body mass and compositions, repeated measures two-way ANOVAs were performed. When main effects or interactions were significant $(P<0.05)$, HolmSidak post hoc tests were performed to determine which combination of conditions were different from one another. To assess differences in treatment on spontaneous physical activity, skeletal muscle contractility, fat pad masses, uterine masses, tibial bone structural and mechanical properties, one-way ANOVAs were performed. When an effect of treatment was significant, Holm-Sidak post hoc measurements were used to determine differences among treatments. When assumptions of equal variance or normality were violated, as assessed by ShapiroWilk testing, Kruskal-Wallis one-way ANOVA on Ranks was performed with Dunn's post hoc tests. For all post hoc testing, $P<0.05$ is considered significant. Statistical analyses were carried out using SigmaStat version 3.5 (Systat Software, Inc., Point Richmond, CA, USA).

\section{Results}

\section{Spontaneous physical activity}

Following 7 week of treatment, 24-h spontaneous physical activities and time being active tended to be low in OVX+BZA mice with ambulation distance significantly less than OVX+placebo mice (Table 1). Although the ANOVA for total active time reached significance, post hoc tests did not identify any treatment group differing from another (Table 1).

\section{Body mass and composition and uterine mass}

All mice gained weight throughout the study with the amount of weight gained in each group dependent upon time (interaction $P<0.001$; Fig. 1A). OVX+placebo mice weighed more than $\mathrm{OVX}+\mathrm{E}_{2}$ mice at week 2 through 8 . $\mathrm{OVX}+\mathrm{BZA}$ mice weighed more than $\mathrm{OVX}+\mathrm{E}_{2}$ mice at week 3 , and weeks 5-8, indicating that BZA treatment did not blunt weight gain as did treatment with $\mathrm{E}_{2}$.

Uterine masses of OVX+placebo and OVX+BZA mice were low compared to $\mathrm{OVX}+\mathrm{E}_{2}$ mice $(P<0.05$; Fig. $1 \mathrm{~B})$. This result indicates that BZA did not stimulate uterine hyperplasia as did $\mathrm{E}_{2}$ in ovariectomized mice.

The percent of body mass that was lean mass changed over the course of the study depending on treatment (interaction $P<0.001$; Fig. 2A). Within groups, $\mathrm{OVX}+$ placebo and OVX+BZA mice had less lean mass at week 8 compared to baseline, and at week 8 had less lean mass compared to $\mathrm{OVX}+\mathrm{E}_{2}$ mice (Fig. 2A). The opposite held for fat mass with mice treated with placebo or BZA, but not $\mathrm{E}_{2}$, gaining fat over the 8-week study (Fig. 2B). The relative adiposity of OVX mice treated with placebo and BZA measured by MRI was corroborated by fat pad masses. Subcutaneous and visceral fat pads from OVX+placebo and OVX+BZA mice weighed $96-126 \%$ more than those from $\mathrm{OVX}+\mathrm{E}_{2}$ mice $(P<0.05$; Fig. $2 \mathrm{C})$.

\section{Skeletal muscle contractile function}

There was no difference in peak isometric torque produced in vivo by the plantar flexor muscles among the treatment groups $(P=0.522$; Fig. $3 \mathrm{~A})$. Over a range of angular velocities, torque production differed at 800 and $1000^{\circ} / \mathrm{s}(P \leq 0.020$; Fig. 3B) between OVX+placebo and $\mathrm{OVX}+\mathrm{E}_{2}$ mice $(P \geq 0.140$ for all other angular velocities; Fig. 3B).

Isolated soleus muscles from OVX+BZA mice weighed more and produced greater peak isometric, concentric and eccentric forces compared to $\mathrm{OVX}+\mathrm{E}_{2}$ mice (Table 2). Once normalized for size, isometric force did not differ significantly among treatment groups (specific $P_{\mathrm{o}}$, Table 2). 

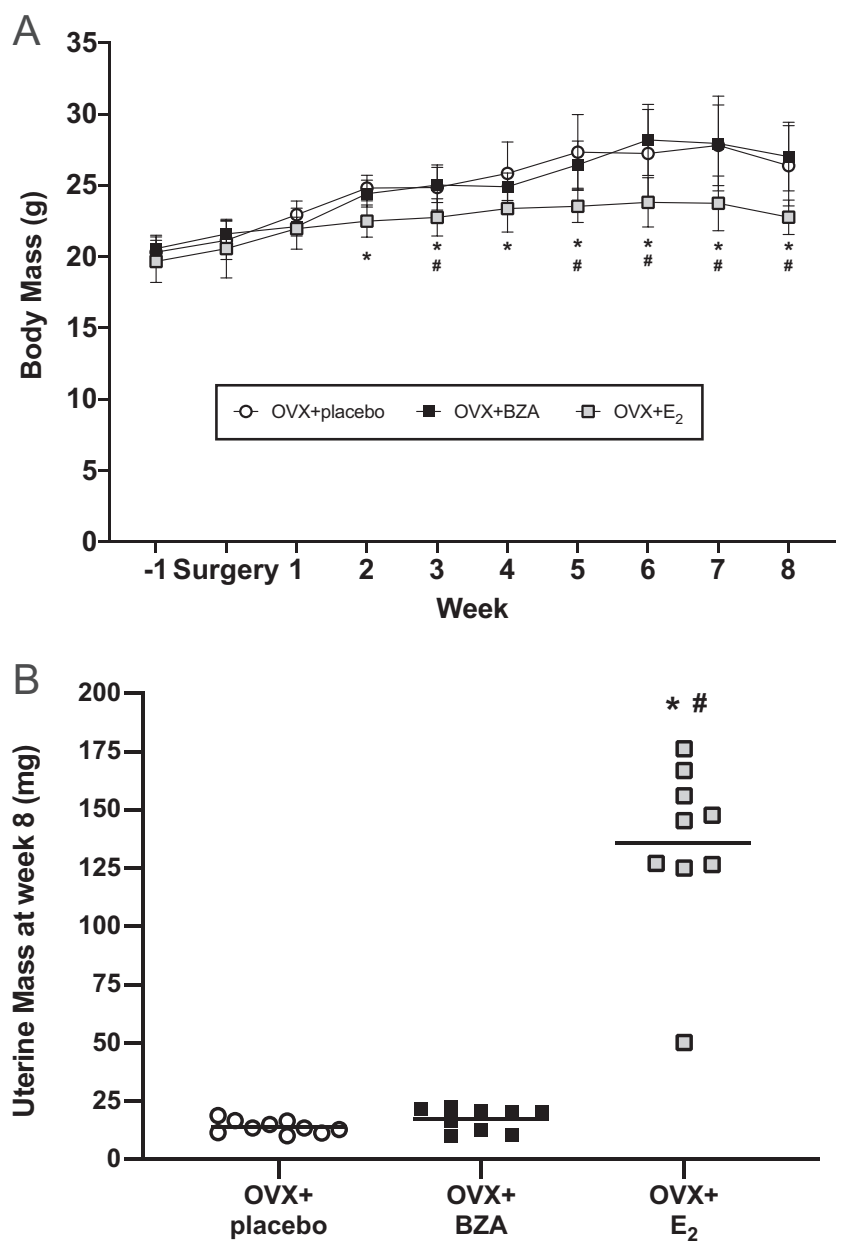

Figure 1

Body masses of mice over the duration of the study and end point uterine masses. (A) Weekly body masses of ovariectomized mice differed among treatment groups depending on time (interaction $P<0.001$ ). Significant results from post hoc testing between groups are denoted at week of treatment. (B) Uterine mass at sacrifice. Data are means \pm S.D. * Different from OVX+placebo. "Different from OVX+BZA.

\section{Cortical structural and mechanical properties of the tibia}

Tibia were imaged at the mid-diaphysis to determine the impact of BZA on cortical bone structure. There was no difference among OVX mice treated with placebo, BZA, and $\mathrm{E}_{2}$ in cortical $\mathrm{BMD}(P=0.528$; Fig. $4 \mathrm{~A})$. Cortical thickness of tibia also did not differ among groups $(P=0.099)$. Cortical cross-sectional area of tibia differed among groups $(P<0.001$; Fig. $4 \mathrm{~B})$ with $\mathrm{OVX}+\mathrm{BZA}$ and $\mathrm{OVX}+\mathrm{E}_{2}$ mice having greater areas than $\mathrm{OVX}+$ placebo, and tibia from OVX+BZA mice having less area than $\mathrm{OVX}+\mathrm{E}_{2}$ mice. Cortical cross-sectional moment of inertia of the tibia differed among groups as well $(P>0.001)$ being greater in OVX+BZA $\left(0.078 \pm 0.005 \mathrm{~mm}^{4}\right)$ than
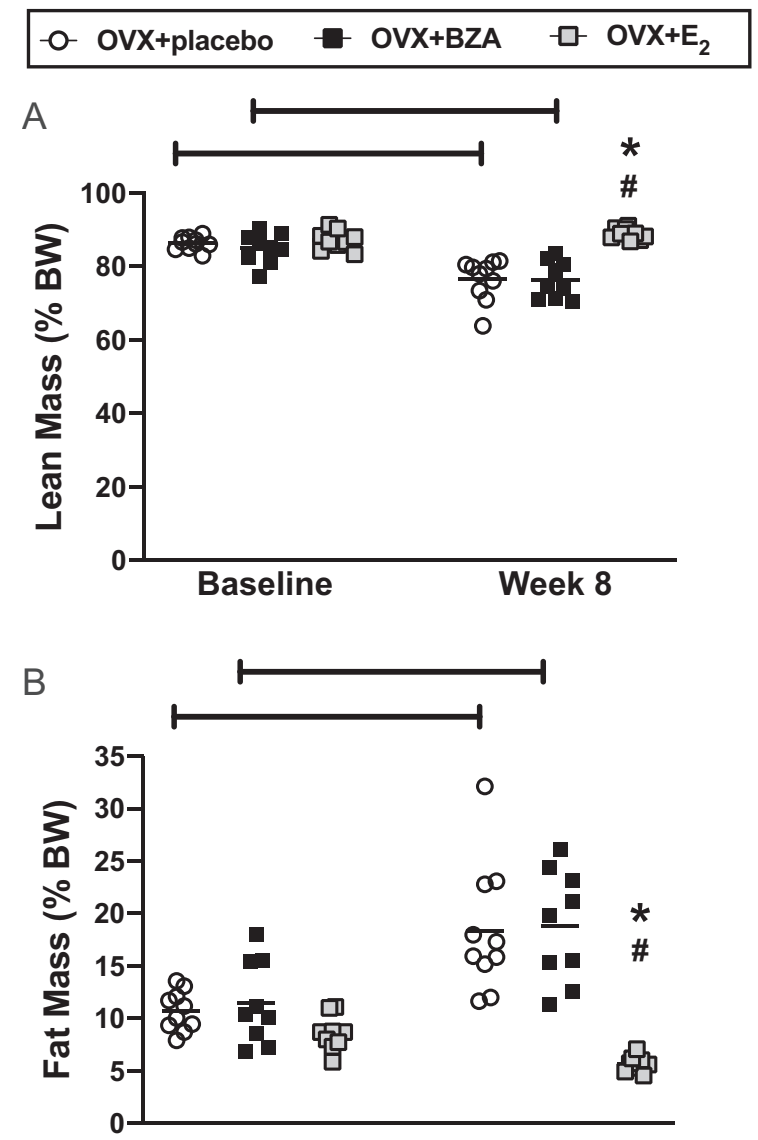

Baseline

Week 8

C

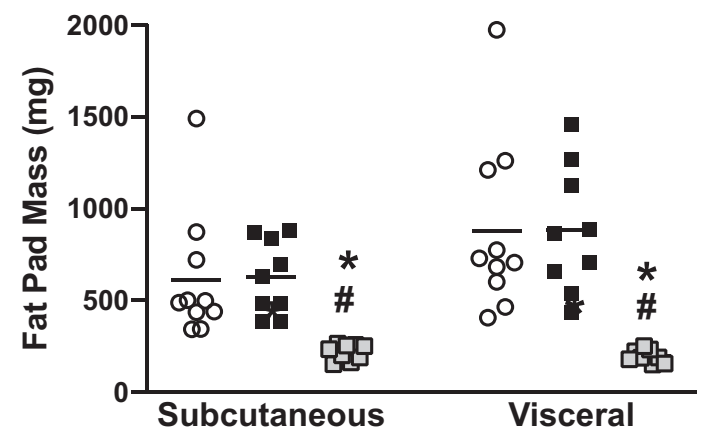

Figure 2

Body composition of ovariectomized mice differed according to treatment group and time (interaction, $P<0.001$ ) and mass of fat pads from ovariectomized mice was low in mice treated with estradiol. (A) Lean mass as a percent of total body mass differed between baseline (pre-surgery) and 8 week after ovariectomy within OVX+placebo and OVX+BZA groups as indicated by horizontal lines. At week 8 , lean mass differed by treatment. (B) Fat mass as a percent of total body mass differed between baseline and 8 weeks after ovariectomy within OVX+placebo and OVX+BZA groups as indicated by horizontal lines. At week 8 , fat mass differed by treatment. (C) Subcutaneous and visceral fat pad masses at sacrifice were affected by treatment. *Different from OVX+placebo within time (or within fat pad in C). \#Different from OVX+BZA within time (or within fat pad in C). Horizontal bars indicate differences between baseline and week 8 within group. 

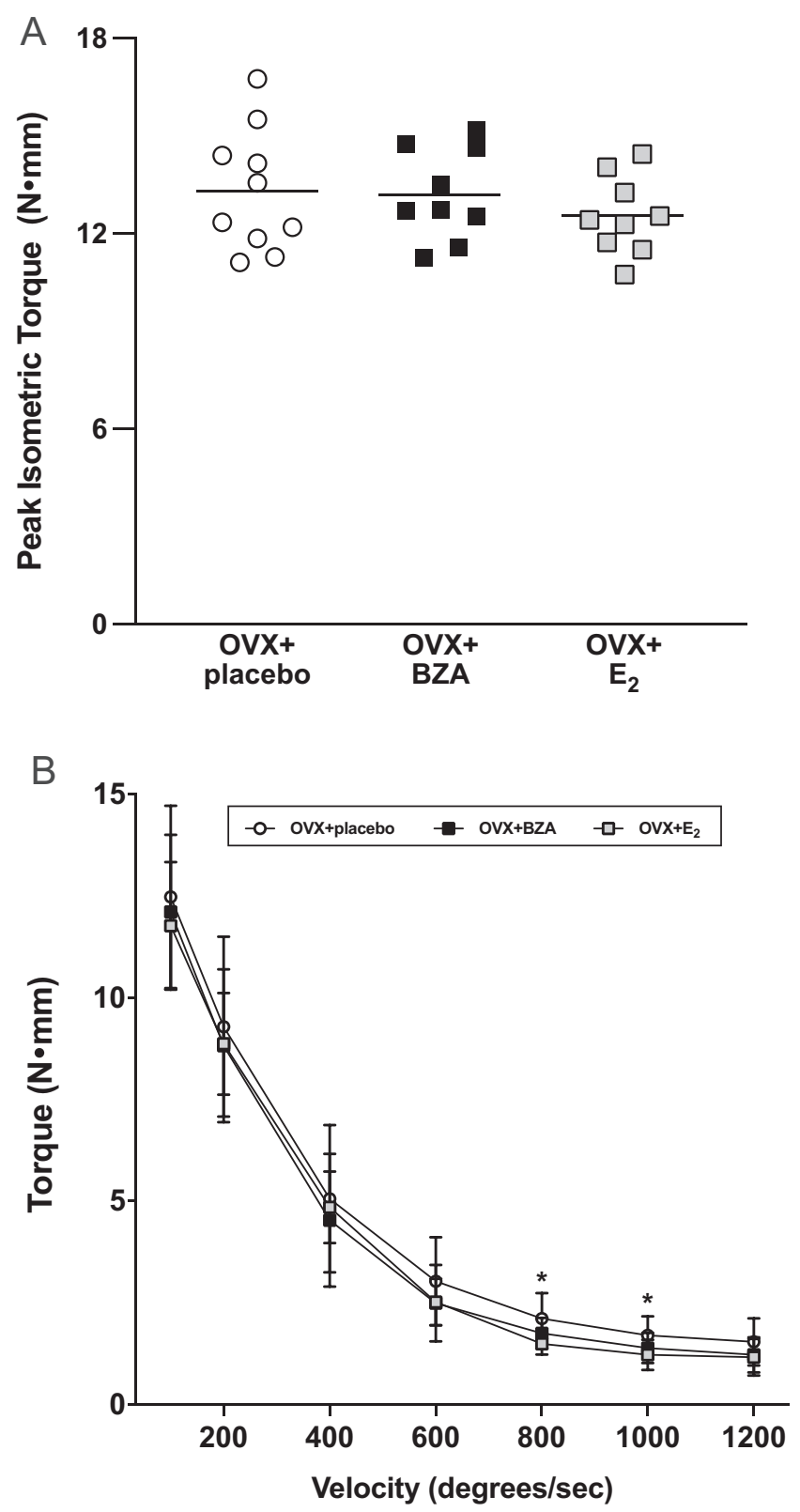

Figure 3

In vivo muscle function of ovariectomized mice minimally differed among treatments. (A) Peak isometric torque of the plantarflexor muscles. (B) Torque production of the plantarflexor muscles at increasing velocities. Data are mean \pm S.D. ${ }^{*} \mathrm{OVX}+\mathrm{E} 2$ different from OVX+placebo.

OVX+placebo $\left(0.068 \pm 0.006 \mathrm{~mm}^{4}\right)$ and $\mathrm{OVX}+\mathrm{E}_{2}$ mice $\left(0.072 \pm 0.006 \mathrm{~mm}^{4}\right)$.

To determine if treatment with BZA improved bone strength, mechanical properties of the tibias were tested. Ultimate load differed among groups $(P=0.033)$ with $\mathrm{OVX}+\mathrm{E}_{2}$ being greater than $\mathrm{OVX}+$ placebo mice (Fig. 4C). There was no difference among groups for tibial bone stiffness $(P=0.086$; Fig. 4D).

\section{Discussion}

This study addressed three hypotheses related to effects of BZA on the musculoskeletal system. First, we did not detect a difference in spontaneous physical activity among the groups and thus were unable to support our hypothesis that BZA treatment would improve spontaneous physical activity more than treatment with placebo. Despite the absence of treatment effect on spontaneous physical activity, we did find effects on body and fat masses. While treatment with placebo and BZA resulted in ovariectomyinduced gains in body and fat masses, treatment with $\mathrm{E}_{2}$ maintained body mass after OVX. Second, BZA treatment preserved soleus muscle mass compared to treatment with $\mathrm{E}_{2}$ contributing to slightly greater isometric, concentric and eccentric force production and providing some support for the hypothesis that BZA is an ER agonist in skeletal muscle. Third, although tibial cortical crosssectional area and cross-sectional moment of inertia were improved with BZA treatment, there was no significant difference between mice treated with placebo and BZA for tibia cortical BMD, ultimate load, or stiffness, thus the hypothesis that BZA would positively affect cortical bone structure and strength was not supported.

Because the function of the musculoskeletal system and physical activity are inherently linked, our experiment first sought to determine if BZA treatment affected spontaneous physical activity. Ovariectomy in rodents typically results in decrements in both spontaneous physical activities as well as voluntary wheel running (Moran et al. 2006, Gorzek et al. 2007, Greising et al. 2011a, Bowen et al. 2012). Two main parameters, ambulation time and total active time, were not different by treatment group though ambulation distance was significantly lower in OVX mice treated with BZA compared to placebo. Previous studies also found no differences in locomotor activity in BZA-treated OVX mice compared to untreated OVX or ovary-intact mice (Barrera et al. 2014, Kim et al. 2014). Because wheel running shows robust responses to manipulation of estrogenic compounds in rodents (Moran et al. 2006, Gorzek et al. 2007, Greising et al. 2011a, Bowen et al. 2012), future studies should consider measuring this type of physical activity. Our results combined with previous studies indicate that any effect of BZA on body composition, skeletal muscle, or bone in mice are not likely related to changes in physical activity.

Inconsistent with previous studies, our results show that BZA did not prevent gains in body and fat masses after OVX. Prior studies reported that BZA prevented OVXinduced weight and fat mass gains in mice (Barrera et al. 
Table 2 In vitro soleus muscle contractile properties of ovariectomized mice treated with placebo, bazedoxifene, or $17 \beta$-estradiol for 8 weeks.

\begin{tabular}{lcc}
\hline & & OVX+Placebo $(n=10)$ \\
\cline { 1 - 2 }$(\mathrm{mg})$ & & $8.48(0.47)$ \\
Peak isometric tetanic force $(\mathrm{mN})$ & $212(26.3)$ \\
Specific $P_{\mathrm{o}}\left(\mathrm{N} / \mathrm{cm}^{2}\right)$ & & $25.4(2.88)$ \\
Peak concentric force $(\mathrm{mN})$ & $108(18.4)$ \\
Peak eccentric force $(\mathrm{mN})$ & $381(49.2)$ \\
\hline
\end{tabular}

\begin{tabular}{c}
\hline OVX+BZA $(n=9)$ \\
\hline $8.69(0.61)$ \\
$234(38.0)$ \\
$27.6(4.80)$ \\
$117(24.0)$ \\
$414(66.2)$ \\
\hline
\end{tabular}

\begin{tabular}{ccc}
\hline $\mathbf{O V X}+\mathbf{E}_{\mathbf{2}}(n=9)$ & & One-way ANOVA P-value \\
\cline { 1 - 1 } $7.59(0.74)^{a}$ & & 0.009 \\
$191(20.7)^{a}$ & & 0.048 \\
$24.0(2.08)$ & & 0.228 \\
$86.7(15.1)^{a}$ & 0.009 \\
$339(39.8)^{a}$ & 0.020 \\
\hline
\end{tabular}

Data are means (S.D.). Specific force $\left(P_{0}\right)$ was calculated as peak isometric tetanic force normalized by muscle physiological cross-sectional area. aDifferent from OVX+BZA.

2014, Kim et al. 2014). A difference between those studies and ours was delivery of BZA; we used subcutaneous time-release pellets whereas other studies used osmotic mini-pumps (Barrera et al. 2014) or oral gavage (Kim et al. 2014). It is possible that the delivery system or dose of the BZA plays a role in the effectiveness of minimizing weight gain, and that the resulting BZA serum concentration we report may have been below the therapeutic range. These results emphasize the importance of measuring and reporting concentrations of SERMs resulting from treatments. Consistent with previous studies (Barrera et al. 2014, Bernardi et al. 2014, Kim et al. 2014, Andersson et al.
$2016 a, b)$, our data clearly indicate that BZA treatment did not increase uterine mass.

A primary objective of our studies was to determine the effects of BZA on the musculoskeletal system. We are aware of only one other study that investigated the effects of a SERM on both skeletal muscle and bone functions. Previously, Warren et al. (2007) treated mice 30 days following OVX with tamoxifen for 60 days. No significant differences between tamoxifen- and $\mathrm{E}_{2}$-treated groups were measured in rescuing maximal isometric tetanic force of the soleus muscle, micro-CT properties of the tibia, or mechanical properties of the tibia, from deleterious effects
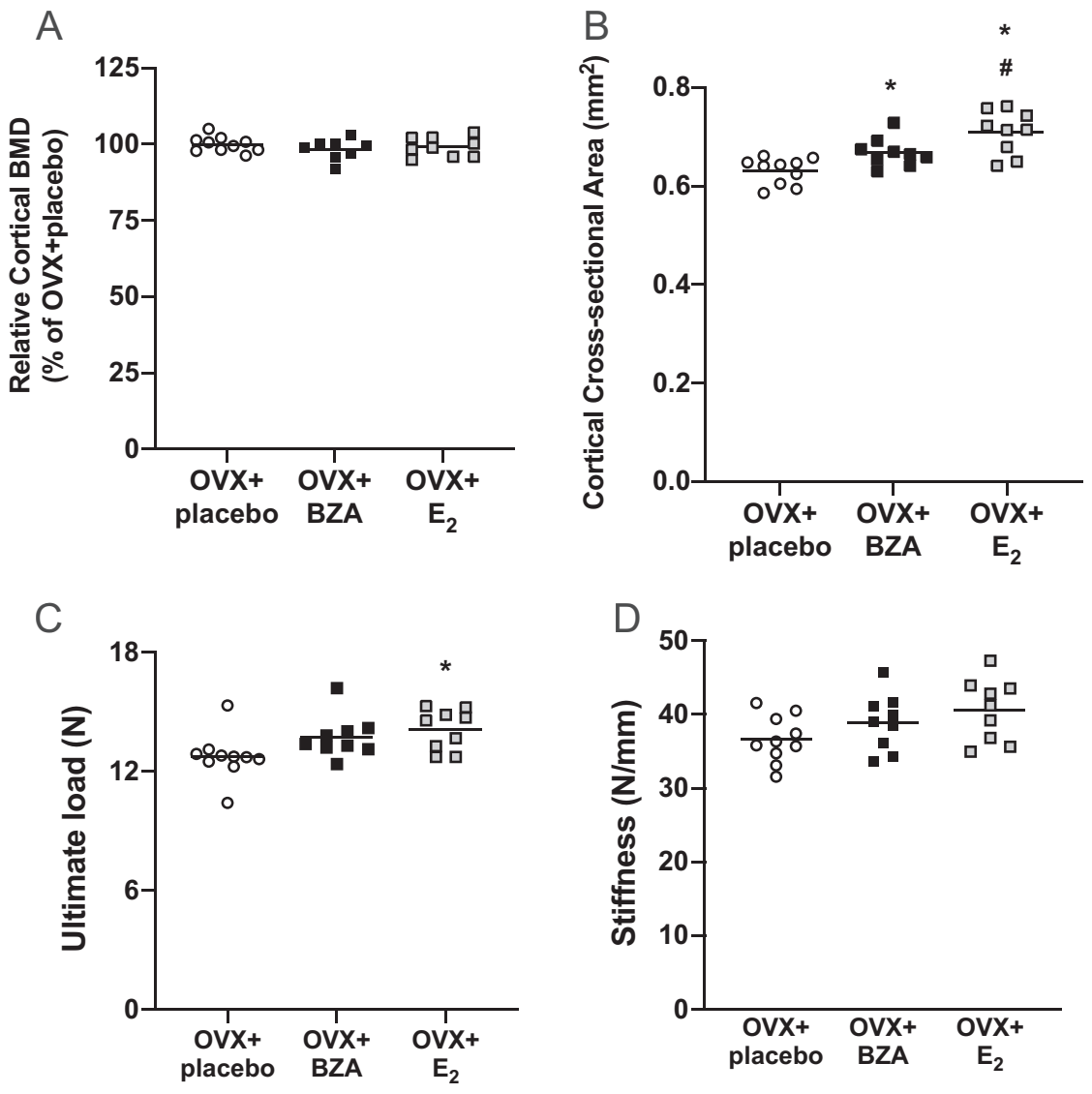
Figure 4
Tibial bone properties from ovariectomized mice were marginally different among the treatment groups. (A) Cortical bone mineral density and (B) cortical cross-sectional area at the mid-diaphysis. (C) Mechanical properties, ultimate load and (D) stiffness. *Different from OVX+placebo. \#Different from OVX+BZA.


of OVX. The conclusion was that tamoxifen is an estrogen receptor agonist in skeletal muscle as well as bone. The current study also evaluated soleus muscle contractility and tibial bone cortical and mechanical properties, with expanded analyses to include measures of in vivo plantar flexor muscle contractility. Our results did not show differences among ovariectomized mice treated with placebo, $\mathrm{E}_{2}$, or BZA in plantar flexor torque production. Soleus muscles from OVX+BZA mice produced greater peak isometric, concentric and eccentric forces than did $\mathrm{OVX}+\mathrm{E}_{2}$ mice; however, once normalized for size, specific force did not differ among treatment groups.

Our imaging results of the mid diaphysis of the tibia showed that BZA increased cortical cross-sectional area and cross-sectional moment of inertia but did not increase cortical BMD. These results are consistent with the results from Andersson et al. (2016a) which showed that BZA increased trabecular but not cortical BMD. In contrast, Komm et al. (2011) demonstrated that BZA treatment was effective in preventing OVX-induced reduction in cortical BMD, however, this was after 52 week of treatment. Our study provided only 8 week of treatment. Additional studies have shown that BZA was effective in preventing OVX-induced decline in BMD, but these studies evaluated total BMD, that is, combining trabecular and cortical bone (Kharode et al. 2008, Bernardi et al. 2014).

There are only two studies that we are aware of which reported the effects of BZA on mechanical properties of bone. Borjesson et al. (2013), demonstrated that treatment with BZA increased maximal load to failure in femurs from orchidectomized male mice compared to femurs from control mice. In female mice, BZA treatment after OVX tended to increase cortical thickness and maximal load to failure but the increases did not reach statistical significance (Börjesson et al. 2016). Similarly, our analysis of bone mechanical properties measured no difference in ultimate load or stiffness between BZA and placebo treatment.

In summary, results of the current study show that BZA has minimal effects within the musculoskeletal system of female mice at the treatment dose used. The SERM caused modest improvements in soleus muscle mass and force production uniquely suggesting that BZA may be an estrogen receptor agonist in skeletal muscle. BZA had positive impacts on some but not all cortical bone structural properties, however, there was no effect of BZA on mechanical properties of tibia. BZA treatment to ovariectomized mice did not prevent body or fat mass gains as did $\mathrm{E}_{2}$ treatment and thus overall did not demonstrate strong estrogenic properties in female mice. Further, results from this study did not appear to be confounded by treatment-induced changes in physical activities by the mice. Future studies are needed to recognize the tissue-selective nature of SERMs, including investigation into effects on multiple tissues and physiological systems.

\section{Declaration of interest}

The authors declare that there is no conflict of interest that could be perceived as prejudicing the impartiality of the research reported.

\section{Funding}

This work was supported by National Institutes of Health Grants R01AG031743, T32-AR007612, T32-AR050938, T32-AG029796 and a Promotion of Doctoral Studies II Scholarship from the Foundation for Physical Therapy.

\section{References}

Anderson GL, Limacher M, Assaf AR, Bassford T, Beresford SAA, Black H, Bonds D, Brunner R, Brzyski R, Caan B, et al. 2004 Effects of conjugated equine estrogen in postmenopausal women with hysterectomy: the Women's Health Initiative randomized controlled trial. JAMA 291 1701-1712. (https://doi.org/10.1001/ jama.291.14.1701)

Andersson A, Bernardi AI, Nurkkala-Karlsson M, Stubelius A, Grahnemo L, Ohlsson C, Carlsten H \& Islander U 2016a Suppression of experimental arthritis and associated bone loss by a tissue-selective estrogen complex. Endocrinology 157 1013-1020. (https://doi. org/10.1210/en.2015-1820)

Andersson A, Bernardi AI, Stubelius A, Nurkkala-Karlsson M, Ohlsson C, Carlsten H \& Islander U 2016b Selective oestrogen receptor modulators lasofoxifene and bazedoxifene inhibit joint inflammation and osteoporosis in ovariectomised mice with collagen-induced arthritis. Rheumatology 55 553-563. (https://doi.org/10.1093/ rheumatology/kev355)

Baltgalvis KA, Call JA, Cochrane GD, Laker RC, Yan Z \& Lowe DA 2012 Exercise training improves plantarflexor muscle function in $\mathrm{mdx}$ mice. Medicine and Science in Sports and Exercise 44 1671-1679. (https://doi.org/10.1249/MSS.0b013e31825703f0)

Barrera J, Chambliss KL, Ahmed M, Tanigaki K, Thompson B, Mcdonald JG, Mineo C \& Shaul PW 2014 Bazedoxifene and conjugated estrogen prevent diet-induced obesity, hepatic steatosis, and type 2 diabetes in mice without impacting the reproductive tract. American Journal of Physiology: Endocrinology and Metabolism 307 E345-E354. (https://doi.org/10.1152/ajpendo.00653.2013)

Bernardi AI, Andersson A, Grahnemo L, Nurkkala-Karlsson M, Ohlsson C, Carlsten H \& Islander U 2014 Effects of lasofoxifene and bazedoxifene on B cell development and function. Immunity, Inflammation and Disease 2 214-225. (https://doi.org/10.1002/iid3.37)

Borjesson AE, Farman HH, Engdahl C, Koskela A, Sjogren K, Kindblom JM, Stubelius A, Islander U, Carlsten H, Antal MC, et al. 2013 The role of activation functions 1 and 2 of estrogen receptoralpha for the effects of estradiol and selective estrogen receptor modulators in male mice. Journal of Bone and Mineral Research $\mathbf{2 8}$ 1117-1126. (https://doi.org/10.1002/jbmr.1842)

Börjesson AE, Farman HH, Movérare-Skrtic S, Engdahl C, Antal MC, Koskela A, Tuukkanen J, Carlsten H, Krust A, Chambon P, et al. 2016 SERMs have substance-specific effects on bone, and these effects are mediated via ER $\alpha \mathrm{AF}-1$ in female mice. American Journal of https://joe.bioscientifica.com

https://doi.org/10.1530/JOE-20-0391 (c) 2021 Society for Endocrinology Published by Bioscientifica Ltd.
Printed in Great Britain 
Physiology: Endocrinology and Metabolism 310 E912-E918. (https://doi. org/10.1152/ajpendo.00488.2015)

Bowen RS, Knab AM, Hamilton AT, Mccall JR, Moore-Harrison TL \& Lightfoot JT 2012 Effects of supraphysiological doses of sex steroids on wheel running activity in mice. Journal of Steroids and Hormonal Science 3 110-110. (https://doi.org/10.4172/2157-7536.1000110)

Cabelka CA, Baumann CW, Collins BC, Nash N, Le G, Lindsay A, Spangenburg EE \& Lowe DA 2019 Effects of ovarian hormones and estrogen receptor alpha on physical activity and skeletal muscle fatigue in female mice. Experimental Gerontology 115 155-164. (https://doi.org/10.1016/j.exger.2018.11.003)

Chandrasekaran A, Ahmad S, Shen L, Demaio W, Hultin T \& Scantina J 2010 Disposition of bazedoxifene in rats. Xenobiotica 40 578-585. (https://doi.org/10.3109/00498254.2010.492879)

Collins BC, Mader TL, Cabelka CA, Inigo MR, Spangenburg EE \& Lowe DA 2018 Deletion of estrogen receptor $\alpha$ in skeletal muscle results in impaired contractility in female mice. Journal of Applied Physiology $\mathbf{1 2 4}$ 980-992. (https://doi.org/10.1152/japplphysiol.00864.2017)

Ettinger B, Wang SM, Leslie RS, Patel BV, Boulware MJ, Mann ME \& Mcbride M 2012 Evolution of postmenopausal hormone therapy between 2002 and 2009. Menopause 19 610-615. (https://doi. org/10.1097/gme.0b013e31823a3e5d)

Farr SA, Flood JF, Scherrer JF, Kaiser FE, Taylor GT \& Morley JE 1995 Effect of ovarian steroids on footshock avoidance learning and retention in female mice. Physiology and Behavior 58 715-723. (https://doi. org/10.1016/0031-9384(95)00124-2)

Garland T, Schutz H, Chappell MA, Keeney BK, Meek TH, Copes LE Acosta W, Drenowatz C, Maciel RC, van Dijk G, et al. 2011 The biological control of voluntary exercise, spontaneous physical activity and daily energy expenditure in relation to obesity: human and rodent perspectives. Journal of Experimental Biology 214 206-229. (https://doi.org/10.1242/jeb.048397)

Gorzek JF, Hendrickson KC, Forstner JP, Rixen JL, Moran AL \& Lowe DA 2007 Estradiol and tamoxifen reverse ovariectomy-induced physical inactivity in mice. Medicine and Science in Sports and Exercise 39 248-256. (https://doi.org/10.1249/01.mss.0000241649.15006.b8)

Greising SM, Baltgalvis KA, Lowe DA \& Warren GL 2009 Hormone therapy and skeletal muscle strength: a meta-analysis. Journals of Gerontology: Series A, Biological Sciences and Medical Sciences 64 1071-1081. (https://doi.org/10.1093/gerona/glp082)

Greising SM, Baltgalvis KA, Kosir AM, Moran AL, Warren GL \& Lowe DA $2011 a$ Estradiol's beneficial effect on murine muscle function is independent of muscle activity. Journal of Applied Physiology 110 109-115. (https://doi.org/10.1152/japplphysiol.00852.2010)

Greising SM, Carey RS, Blackford JE, Dalton LE, Kosir AM \& Lowe DA $2011 b$ Estradiol treatment, physical activity, and muscle function in ovarian-senescent mice. Experimental Gerontology 46 685-693. (https://doi.org/10.1016/j.exger.2011.04.006)

Harvey JA, Pinkerton JV, Baracat EC, Shi H, Chines AA \& Mirkin S 2013 Breast density changes in a randomized controlled trial evaluating bazedoxifene/conjugated estrogens. Menopause 20 138-145. (https:// doi.org/10.1097/gme.0b013e318271f5e7)

Kharode Y, Bodine PVN, Miller CP, Lyttle CR \& Komm BS 2008 The pairing of a selective estrogen receptor modulator, bazedoxifene, with conjugated estrogens as a new paradigm for the treatment of menopausal symptoms and osteoporosis prevention. Endocrinology 149 6084-6091. (https://doi.org/10.1210/en.2008-0817)

Kim JH, Meyers MS, Khuder SS, Abdallah SL, Muturi HT, Russo L, Tate CR, Hevener AL, Najjar SM, Leloup C, et al. 2014 Tissue-selective estrogen complexes with bazedoxifene prevent metabolic dysfunction in female mice. Molecular Metabolism 3 177-190. (https://doi. org/10.1016/j.molmet.2013.12.009)

Komm BS, Vlasseros F, Samadfam R, Chouinard L \& Smith SY 2011 Skeletal effects of bazedoxifene paired with conjugated estrogens in ovariectomized rats. Bone 49 376-386. (https://doi.org/10.1016/j. bone.2011.05.024)
Lai S, Collins BC, Colson BA, Kararlgas G \& Lowe DA 2016 Estradiol modulates myosin regulatory light chain phosphorylation and contractility in skeletal muscle of female mice. American Journal of Physiology: Endocrinology and Metabolism 310 E724-E733. (https://doi. org/10.1152/ajpendo.00439.2015)

Landisch RM, Kosir AM, Nelson SA, Baltgalvis KA \& Lowe DA 2008 Adaptive and nonadaptive responses to voluntary wheel running by mdx mice. Muscle and Nerve 38 1290-1303. (https://doi.org/10.1002/ mus.21141)

Le G, Novotny SA, Mader TL, Greising SM, Chan SSK, Kyba M, Lowe DA \& Warren GL 2018 A moderate estradiol level enhances neutrophil number and activity in muscle after traumatic injury but strength recovery is accelerated. Journal of Physiology 596 4665-4680. (https:// doi.org/10.1113/JP276432)

Lemoine S, Granier P, Tiffoche C, Rannou-Bekono F, Thieulant ML \& Delamarche P 2003 Estrogen receptor alpha mRNA in human skeletal muscles. Medicine and Science in Sports and Exercise 35 439-443. (https://doi.org/10.1249/01.MSS.0000053654.14410.78)

Mader TL, Novotny SA, Lin AS, Guldberg RE, Lowe DA \& Warren GL 2014 CCR2 elimination in mice results in larger and stronger tibial bones but bone loss is not attenuated following ovariectomy or muscle denervation. Calcified Tissue International 95 457-466. (https://doi. org/10.1007/s00223-014-9914-z)

Moran AL, Warren GL \& Lowe DA 2005 Soleus and EDL muscle contractility across the lifespan of female C57BL/6 mice. Experimental Gerontology 40 966-975. (https://doi.org/10.1016/j.exger.2005.09.005)

Moran AL, Warren GL \& Lowe DA 2006 Removal of ovarian hormones from mature mice detrimentally affects muscle contractile function and myosin structural distribution. Journal of Applied Physiology $\mathbf{1 0 0}$ 548-559. (https://doi.org/10.1152/japplphysiol.01029.2005)

Nelson JF, Felicio LS, Osterburg HH \& Finch CE 1981 Altered profiles of estradiol and progesterone associated with prolonged estrous cycles and persistent vaginal cornification in aging C57BL/6J mice. Biology of Reproduction 24 784-794. (https://doi.org/10.1095/ biolreprod24.4.784)

North American Menopause Society 2004 Treatment of menopauseassociated vasomotor symptoms: position statement of the North American Menopause Society. Menopause 11 11-33. (https://doi. org/10.1097/01.GME.0000108177.85442.71)

Novotny SA, Warren GL, Lin AS, Guldberg RE, Baltgalvis KA \& Lowe DA 2011 Bone is functionally impaired in dystrophic mice but less so than skeletal muscle. Neuromuscular Disorders 21 183-193. (https:// doi.org/10.1016/j.nmd.2010.12.002)

Phillips SK, Rook KM, Siddle NC, Bruce SA \& Woledge RC 1993 Muscle weakness in women occurs at an earlier age than in men, but strength is preserved by hormone replacement therapy. Clinical Science $\mathbf{8 4}$ 95-98. (https://doi.org/10.1042/cs0840095)

Pickar JH, Yeh IT, Bachmann G \& Speroff L 2009 Endometrial effects of a tissue selective estrogen complex containing bazedoxifene/conjugated estrogens as a menopausal therapy. Fertility and Sterility 92 1018-1024. (https://doi.org/10.1016/j.fertnstert.2009.05.094)

Pinkerton JV, Utian WH, Constantine GD, Olivier S \& Pickar JH 2009 Relief of vasomotor symptoms with the tissue-selective estrogen complex containing bazedoxifene/conjugated estrogens: a randomized, controlled trial. Menopause 16 1116-1124. (https://doi. org/10.1097/gme.0b013e3181a7df0d)

Pinkerton JV, Harvey JA, Lindsay R, Pan K, Chines AA, Mirkin S, Archer DF \& SMART-5 Investigators 2014 Effects of bazedoxifene/ conjugated estrogens on the endometrium and bone: a randomized trial. Journal of Clinical Endocrinology and Metabolism 99 E189-E198. (https://doi.org/10.1210/jc.2013-1707)

Reagan-Shaw S, Nihal M \& Ahmad N 2008 Dose translation from animal to human studies revisited. FASEB Journal 22 659-661. (https://doi. org/10.1096/fj.07-9574LSF)

Ribas V, Drew BG, Zhou Z, Phun J, Kalajian NY, Soleymani T, Daraei P, Widjaja K, Wanagat J, De Aguiar Vallim TQ, et al. 2016 Skeletal muscle https://joe.bioscientifica.com https://doi.org/10.1530/JOE-20-0391 (c) 2021 Society for Endocrinology Published by Bioscientifica Ltd. Printed in Great Britain 
action of estrogen receptor alpha is critical for the maintenance of mitochondrial function and metabolic homeostasis in females. Science Translational Medicine 8 334ra54. (https://doi.org/10.1126/ scitranslmed.aad3815)

Ronkainen PH, Kovanen V, Alen M, Pollanen E, Palonen EM, AnkarbergLindgren C, Hamalalnen E, Turpelnen U, Kujala UM, Puolakka J, et al. 2009 Postmenopausal hormone replacement therapy modifies skeletal muscle composition and function: a study with monozygotic twin pairs. Journal of Applied Physiology 107 25-33. (https://doi. org/10.1152/japplphysiol.91518.2008)

Saito M, Kida Y, Nishizawa T, Arakawa S, Okabe H, Seki A \& Marumo K 2015 Effects of 18-month treatment with bazedoxifene on enzymatic immature and mature cross-links and non-enzymatic advanced glycation end products, mineralization, and trabecular microarchitecture of vertebra in ovariectomized monkeys. Bone $\mathbf{8 1}$ 573-580. (https://doi.org/10.1016/j.bone.2015.09.006)

Silverman SL, Christiansen C, Genant HK, Vukicevic S, Zanchetta JR, De Villiers TJ, Constantine GD \& Chines AA 2008 Efficacy of bazedoxifene in reducing new vertebral fracture risk in postmenopausal women with osteoporosis: results from a 3-year, randomized, placebo-, and active-controlled clinical trial. Journal of Bone and Mineral Research 23 1923-1934. (https://doi.org/10.1359/ jbmr.080710)

Smith SY, Jolette J, Chouinard L \& Komm BS 2015 The effects of bazedoxifene in the ovariectomized aged cynomolgus monkey.
Journal of Bone and Mineral Metabolism 33 161-172. (https://doi. org/10.1007/s00774-014-0580-z)

Smitha G, Reddy SS, Rasaga M, Priyanka R, Bakshi V \& Jukant IR 2015 Bazedoxifene acetate quantification in rat serum with the aid of RP-HPLC: method development and validation. World Journal of Pharmaceutical Sciences 3 2357-2363.

Wardell SE, Nelson ER, Chao CA \& Mcdonnell DP 2013 Bazedoxifene exhibits antiestrogenic activity in animal models of tamoxifenresistant breast cancer: implications for treatment of advanced disease. Clinical Cancer Research 19 2420-2431. (https://doi. org/10.1158/1078-0432.CCR-12-3771)

Warren GL, Moran AL, Hogan HA, Lin AS, Guldberg RE \& Lowe DA 2007 Voluntary run training but not estradiol deficiency alters the tibial bone-soleus muscle functional relationship in mice. American Journal of Physiology: Regulatory, Integrative and Comparative Physiology 293 R2015-R2026. (https://doi.org/10.1152/ajpregu.00569.2007)

Wiik A, Glenmark B, Ekman M, Esbjornsson-Lijedahl M, Johansson O, Bodin K, Enmark E \& Jansson E 2003 Oestrogen receptor beta is expressed in adult human skeletal muscle both at the mRNA and protein level. Acta Physiologica Scandinavica 179 381-387. (https://doi. org/10.1046/j.0001-6772.2003.01186.x)

Wiik A, Ekman M, Johansson O, Jansson E \& Esbjornsson M 2009 Expression of both oestrogen receptor alpha and beta in human skeletal muscle tissue. Histochemistry and Cell Biology 131 181-189. (https://doi.org/10.1007/s00418-008-0512-x)

Received in final form 23 November 2020

Accepted 8 December 2020

Accepted Manuscript published online 9 December 2020 (c) 2021 Society for Endocrinology Published by Bioscientifica Ltd. Printed in Great Britain 